\title{
Analysing intersecting social inequalities in crisis settings
}

Becky Carter

Institute of Development Studies

5 January 2022

\section{Question}

What are the frameworks for analysing intersecting social inequalities in crisis settings, and what learning is there on good practice for undertaking this type of analysis?

\section{Contents}

1. Summary

2. Why analyse intersecting social inequalities in crisis settings?

3. Analytical frameworks

4. Lessons learned

5. Appendix: Overview of analytical frameworks

6. References

The K4D helpdesk service provides brief summaries of current research, evidence, and lessons learned. Helpdesk reports are not rigorous or systematic reviews; they are intended to provide an introduction to the most important evidence related to a research question. They draw on a rapid deskbased review of published literature and consultation with subject specialists.

Helpdesk reports are commissioned by the UK Foreign, Commonwealth, \& Development Office and other Government departments, but the views and opinions expressed do not necessarily reflect those of FCDO, the UK Government, K4D or any other contributing organisation. For further information, please contact helpdesk@k4d.info. 


\section{Summary}

Analysis of intersecting social inequalities is key to effective, inclusive interventions in crisis settings. Gender equality and social inclusion analytical frameworks provide key research questions and participatory methodologies which seek to understand: Who is excluded? How are they excluded? Why are they excluded? What can be done to address this and support greater inclusion? There is a focus on underlying power dynamics, drivers of marginalisation, and entry points for external support. Other analytical frameworks - such as political economy analyses, conflict analyses and humanitarian needs assessments - may integrate a gender-sensitive or intersectional diagnostic lens (but do not always). Learning on undertaking analysis of intersecting social inequalities in crisis contexts centres around three key themes: 1) embedding the analysis in strategy and programme decision-making; 2) planning a conflict-sensitive analytical process that is centred around ethics, inclusive engagement and safeguarding; and 3) approaches for applying an intersectional analytical lens.

This rapid review presents a summary of relevant analytical frameworks and good practice for analysing intersecting social inequalities in crisis settings. ${ }^{1}$ The focus is on how to undertake contextual analysis of the vulnerabilities and needs of people in crises that are shaped by overlapping and compounding social inequalities, arising from discrimination based on gender, age, disability, sexual orientation, gender identity and/or expression and sex characteristics, ethnicity and religion (among other identifiers).

The review draws on and presents prior research undertaken for FCDO that identified relevant analytical frameworks, learning and key resources on how to undertake this type of analysis, through a rapid literature search and input by key experts. ${ }^{2}$ It summarises a range of frameworks relevant for analysing intersecting social inequalities in crisis settings, developed for various development, humanitarian and peacebuilding objectives. It was harder to find published learning from undertaking this analysis that focuses specifically on crisis settings, but it was possible to draw findings from some individual case studies as well as relevant summaries of learning presented in the analytical frameworks and other guidance materials.

\section{Key findings}

\section{Why analyse intersecting social inequalities in a crisis?}

There is growing evidence that, to be effective, external support in crisis settings needs to understand how people's vulnerabilities, needs and resilience are shaped by overlapping social inequalities deriving from discrimination and marginalisation. This involves understanding how these intersections compound disadvantage and that people's lived experiences cannot be understood by studying individual categories of difference separately.

Analysis of intersecting social inequalities in crisis settings is typically undertaken to support inclusive approaches to development, humanitarian and peacebuilding goals and interventions. Social inclusion objectives for external assistance exist on a continuum, from minimal (i.e. do no

\footnotetext{
${ }^{1}$ For this review, 'crisis setting' is interpreted broadly to cover analysis in fragile and conflict-affected states, in particular those affected by rapid-onset and protracted crises; and climate, disaster, pandemic and conflict emergencies.

2 This helpdesk report is based on, and uses the findings and key sections of text, from a related FCDO internal learning review. It also includes findings from subsequent additional literature searches.
} 
harm, non-discrimination), to equitable access and meaningful participation, to transformational (i.e. changing norms and power relations).

What are the frameworks for analysing intersecting social inequalities in crisis settings?

Analytical frameworks for contextual analysis of intersecting social inequalities to inform donor strategies and programmes are still relatively rare, with no distinct widely accepted set of methods. This rapid review presents a brief overview of (traditionally siloed) frameworks that have been developed for analysis of exclusion, vulnerability, needs and resilience within development, conflict and peacebuilding, and humanitarian fields. Some are specifically for crisis settings; some are designed for sector analysis; some have a primary gender focus; others start from a broader social inclusion perspective. The frameworks set out theoretical models, key research questions and guidance on conducting the analysis. Sometimes termed gender equality and social inclusion (GESI) analytical frameworks, the frameworks that focus on analysing intersecting social inequalities are concerned with understanding underlying power dynamics, and how these work to maintain social exclusion and inequalities across interrelated domains. They seek to examine the drivers of inequalities as well as the manifestations. They include a focus on analysing what can be done to support inclusion, from using the analysis to ensure donors do no harm, to identifying entry points and actors to work with.

What learning is there on good practice for undertaking this type of analysis?

Three key themes emerge from the learning on undertaking analysis of intersecting inequalities in crisis settings:

- A focus on embedding analyses in strategy and programme decision-making, by moving away from one-off products to on-going analysis adaptive to changing contexts (Christian Aid and Social Development Direct, 2021a); starting analysis early enough to inform strategic priorities and design decisions; and supporting staff engagement and take-up of findings. On the latter, possible tactics include organisational policy, strategy and programme commitments and initiatives; involving staff across operational processes and hierarchy; participatory approaches with staff building on their own insights and knowledge to produce an analysis; and follow-up activities (action-oriented workshops and monitoring process and outcome indicators).

- The critical importance of planning the analytical process in crisis settings with due consideration to ethics, inclusive engagement and safeguarding. This includes the need to adopt a conflict sensitive approach; develop ethical standards and guidelines; plan for potential ethical dilemmas, risks and safeguarding, including a referral process for safeguarding issues that may arise during and after the analytical process. There is another set of learning around inclusive engagement with stakeholders (drawing on tools for conducting participatory and inclusive research). This includes collaborating with local experts and civil society organisations (while being alert to whose voices are being heard and whose are not within organisations and the research process in order to not perpetuate patterns of exclusion). Another set of findings highlights how such analysis can be politically sensitive, and may meet local resistance to inclusive engagement.

- Learning on applying an intersectional analytical lens. This includes ensuring the analysis is contextualised - for example by investigating what is happening locally rather than applying a generic checklist of social identifiers. A key point is to start with a review of existing evidence and analysis, to avoid duplication of effort and help identify appropriate 
analytical entry points. There is a set of findings around the need to go beyond a single 'vulnerable group' perspective, and understand how underlying power dynamics shape people's life experiences, and using a systems approach to identify links between drivers and dimensions of exclusion, which are often compounded and overlapping, as well as opportunities for influence. Lastly, there is also a set of recommendations around taking into account commonly neglected issues when analysing intersecting social inequalities: resilience and areas of agency and empowerment; men and boys and masculinities.

\section{Why analyse intersecting social inequalities in crisis settings?}

Donors and other development actors are increasingly interested in analysing intersecting social inequalities to inform their strategic priorities and programme design, with the end goal of achieving development, humanitarian and peacebuilding objectives as set out in the Sustainable Development Goals and the commitment to Leave No One Behind. This type of analysis allows us to understand the intersecting social inequalities that perpetuate deprivation and exacerbate vulnerability to crises, which are in turn drivers of fragility that constrain development, peacebuilding and humanitarian objectives (OECD, 2021: 6).

Across various academic fields and development organisations there is increasing awareness of how different aspects of social identity and discrimination 'converge to produce particular experiences of marginalisation' (Baird et al., 2021: 1149), and the implications of this for external development assistance. Analysing inequalities with an intersectional lens derives from a diagnostic approach termed 'intersectionality'. This approach draws on work by Black feminist scholars, notably Crenshaw (1989) (ibid.). ${ }^{3}$ Key highlights on the focus and value of an intersectional lens include:

- Firstly, that social inequalities and discrimination can lead to social exclusion when individuals or groups are unable to participate in the economic, social, political and cultural life of their society due to their race, gender, sexuality, religion, class, disability, age, or other category of difference' (CIVICUS, 2020: 8). This exclusion (or marginalisation) occurs through formal and informal institutions and 'behaviors and practices, including stereotypes, prejudices, and stigmas that are socially constructed and influence day-today interactions' (World Bank, 2013: 77).

- Secondly, that these experiences of disadvantage can be compounded by intersecting identities: for example, 'the intersection of gender, age, ethnicity, and place of residence can have significantly more deleterious effects than the effects of gender alone' (World Bank, 2013: 7). Intersectionality considers the interaction between social categories that

${ }^{3}$ In the late 1980s, Kimberlé Crenshaw coined the concept of intersectionality:

'Concerned with overcoming the discriminatory situation faced by black women workers at General Motors, Crenshaw demonstrated the inadequacy of existing categories denoting gender and race as grounds for legal action, since these could not be mobilized simultaneously in the case of a given individual: you had to be either a woman or nonwhite, but not both at the same time. Crenshaw famously developed the metaphor of a crossroads of two avenues, one denoting race, the other gender, to make the point that accidents occurring at the intersection could not be attributed to solely one cause; it took motion along two axes to make an accident happen (Crenshaw, 1989).' (Foley 2018: 270) 
are 'fixed (e.g. race, ethnicity) or fluid (e.g. geography, occupation, migration status)' (Wolfe et al., 2017).

- Thirdly, that the experience of exclusion, and barriers to inclusion, cannot be understood by studying disability, race and ethnicity, gender or other identities separately: it is in the intersection of these that a person's particular experience of marginalisation is formed (IASC, 2019: 10, cited in Barbelet and Wake, 2020: 14).

- Fourthly, that, because of intersecting inequalities and discrimination, while social inclusion may involve poverty reduction, 'it is often about more than poverty, and in some cases, it is not about poverty at all' (World Bank, 2013: 4).

There is growing evidence that to be effective and inclusive, external support, including in a crisis, needs to start by understanding how people's vulnerabilities, needs and resilience are shaped by overlapping and often compounding social inequalities and discrimination. Some examples of the evidence base include:

- A recent K4D rapid review looking at evidence on vulnerability to disasters, conflict and other humanitarian crises found that intersecting social inequalities shape risk and capacity during crises, through several separate potential channels for disproportionate adverse effects (Carter, 2021: 3). These include limited resilience and heightened exposure; vulnerability to targeted protection threats; vulnerability to deprivation; and risk of exclusion from humanitarian assistance (ibid.).

- Analyses of COVID-19 health impacts and the socio-economic consequences of lockdowns and other virus containment policies have illuminated and exacerbated preexisting intersecting social inequalities, shaping who has been most at risk during the crisis (see for example, Maestripieri, 2021; Birchall, 2021).

- Barbelet et al.'s (2021) case study of exclusion and inclusion in the humanitarian response in north-east Nigeria lays bare the consequences of not understanding intersecting inequalities and wider social exclusion drivers. They find that in north-east Nigeria 'The nature and scale of the crisis means that macro-level operational challenges took up most financial and human capital, leading to a de-prioritisation of inclusion' (ibid.: 9). They conclude that 'the lack of secondary-level assessments and analysis on intersecting drivers of exclusion meant that humanitarian actors were unaware of such drivers and did not integrate them to inform their understanding of vulnerability and needs. This compounded aid actors contributing to exclusion as the response adopted ineffective community engagement approaches and lacked proximity to people affected by the conflict.' (ibid.)

Analysis of intersecting social inequalities is typically undertaken to support inclusive approaches, which aim to improve 'the ability, opportunity and dignity of people, disadvantaged on the basis of their identity, to take part in society' (World Bank, 2013: 110). In a crisis setting, inclusive approaches may aim to support (any combination of) development, humanitarian and peacebuilding goals and interventions. Social inclusion objectives for external assistance exist on a continuum, from minimal (i.e. do no harm, non-discrimination), to equitable access and meaningful participation, to transformational (i.e. changing norms and power relations) (expert comment). 


\section{Analytical frameworks}

Analytical frameworks ${ }^{4}$ for contextual analysis of intersecting social inequalities to inform donor strategies and programmes are still relatively rare. There is not one widely accepted set of methods for this type of analysis (Chaplin et al., 2019: 20; George et al., 2021: 2-3; Searle et al., 2016: 15, cited in Barbelet and Wake, 2020: 28). The analytical frameworks found by this rapid review have been developed within (traditionally siloed) development, conflict and peacebuilding, and humanitarian fields. They may be concerned with inequalities and the causes of these at country, thematic or programme levels (DFID, 2009b: 8). Some have a primary gender focus; others start from a wider social inclusion perspective. Some are designed for crisis settings; others are not, but provide additional insights which have relevance. However, notwithstanding differences in objectives and scope, the frameworks have complementarities in theoretical perspectives, research focus and questions, and methodologies. In terms of content, most analytical guidance includes recommendations on how to conduct analysis, as well as setting out theoretical models and key research questions.

Here is a brief overview of analytical frameworks for gender equality and social inclusion analysis; gender-sensitive conflict analysis; and humanitarian vulnerability and resilience analysis and needs assessments. For a more detailed summary of the individual frameworks (and links to them), see the appendix in Section 5.

\section{Gender equality and social inclusion analysis}

Examples of gender equality and social inclusion (GESI) analytical frameworks include: How To Note on Gender and Social Exclusion Analysis ${ }^{5}$ (DFID, 2009a); Social Inclusion Assessment Tool ${ }^{6}$ (World Bank, 2018), based on the analytical framing set out in the World Bank's flagship 2013 report Inclusion Matters; Gender, Inclusion, Power and Politics Analysis Toolkit (Christian Aid and Social Development Direct, 2021a, b); and Social Inclusion Tool ${ }^{8}$ (CIVICUS, 2020). These frameworks are designed for use in varied contexts. Applying them in a crisis setting requires careful consideration of context- and crisis-specific sensitivities. The key research questions across the frameworks converge on unpacking the following concerns (World Bank, 2018):

- Who is excluded and how are they likely to be excluded?

- Why are they likely to be excluded?

- What can be done to address this and support greater inclusion?

\footnotetext{
4 'Analytical frameworks are essentially a methodological ecosystem aiming at guiding and facilitating sense making and understanding' (Chataigner, 2017: 6 - italics in original report). An analytical framework helps approach a problem logically and systematically, breaking down an issue into subcomponents, guiding data collection and analysis. An analytical framework can set out methods of research and planning, including how to undertake data collection and analysis. (ibid.; March et al., 1999: 11)

${ }^{5}$ http://www.gsdrc.org/docs/open/se9.pdf (see Section 5 for a summary)

${ }^{6}$ https://thedocs.worldbank.org/en/doc/4780715405911642600200022018/original/SiATSociallnclusionAssessmentTool.pdf (see Section 5 for a summary)

7 https://evidenceforinclusion.org/gipp-toolkit/ (see Section 5 for a summary)

${ }^{8} \mathrm{http}: / /$ civicus.org/documents/Social_Inclusion_Toolkit.pdf (see Section 5 for a summary)
} 
There are also GESI toolkits from individual sectors of intervention. One example is the World Health Organization (WHO) toolkit on incorporating intersectional gender analysis into research on infectious diseases ${ }^{9}$ (WHO, 2020). One expert consulted highlighted that sectoral analysis of intersecting inequalities may need tailored analytical frameworks and guiding questions, as there will be sector-specific issues to be aware of and take into account in the analysis. For example, GESI analysis undertaken to inform the provision of girls' education in emergencies would benefit from the learning presented in Guglielmi et al. (2021), which highlights the need for genderresponsive, adaptable and inclusive planning tools.

Some frameworks focus on gender and use this primary gender focus as an entry point for consideration of other intersecting inequalities (see WHO, 2020). Others come from the tradition of political economy analysis. See, for example, guidance by Haines and O'Neil ${ }^{10}(2018)$ on how to undertake a gendered political economy analysis. The Christian Aid and Social Development Direct $(2021 \mathrm{a}, \mathrm{b})$ analysis toolkit is a deliberate attempt to integrate gender and inclusion analyses with approaches found in power analysis and political economy analysis.

While there are differences in research focus, a key similarity is that the frameworks are concerned in some way with power dynamics and how these work to maintain social exclusion and inequalities. More recent analytical frameworks covered in this review place power explicitly at the centre of their analysis. These frameworks consider different forms of power (visible, hidden and invisible $)^{11}$ and explore how these inclusion and exclusion dynamics work across interrelated domains, which they define in various ways: markets, services and spaces (World Bank, 2018); society, the state and the market (DFID, 2009a); access to resources; division of labour, roles and everyday practices; social norms and values; and rules and decision-making (WHO, 2020). This explicit focus on power signals that these frameworks seek to examine the drivers of inequalities as well as the manifestations.

The frameworks also include a focus on analysing what can be done to support inclusion, from using the analysis to ensure donors do no harm, to identifying entry points and actors to work with. For example, Christian Aid and Social Development Direct (2021a: 13) includes research questions on 'incentives, barriers and potential new pathways for change' and 'how to enhance the agency and voice of people who are excluded'.

On the analytical process itself, these frameworks range from providing brief recommendations to in-depth guidance (and practical tools) for participatory (and, in some cases, transformative) research processes (see Christian Aid and Social Development Direct, 2021a, b; and WHO, 2020).

\section{Gender-sensitive conflict analysis}

Attempts to integrate a focus on intersecting inequalities in conflict analyses are limited (OECD, 2021: 7). For example, when gender is considered, the focus tends to be only on conflict impacts, and not how gender norms ('the societal expectations of the roles and behaviours of people') can

\footnotetext{
${ }^{9}$ https://www.who.int/tdr/publications/year/2020/tdr-intersectional-gender-toolkit/en/ (see Section 5 for a summary)

${ }^{10}$ https://gadnetwork.org/gadn-resources/2018/5/9/putting-gender-in-political-economy-analysis-whyit-matters-and-how-to-do-it (see Section 5 for a summary)

${ }^{11}$ These three faces (or forms) of power build on Lukes (1974), Gaventa (1982) and especially VeneKlasen with Miller (2002).
} 
be drivers of conflict (Close et al., 2020: 4). Alder (2021: 1) notes that 'While different aspects of identity are increasingly understood to shape diverse experiences of, and agency within conflict, religion and gender are still often treated as separate categories'. Looking at how religion and gender intersect to shape conflict experiences in Nigeria, Myanmar and the US, she finds that intersectional analysis of gender and religion 'as overlapping rather than parallel categories' enables 'a thorough understanding of conflict dynamics and inclusive peace programming strategies' (ibid.).

One example of a published conflict and peacebuilding analytical framework with an intersectional lens is the Conciliation Resources and Saferworld facilitation guide to gender-sensitive conflict analysis $^{12}$ (Close et al., 2020). From a primary gender focus, it recommends applying an intersectional lens:

'This means considering the multiple ways that systems of power - such as ethnicity, race, age, socio-economic status, religion, (dis)ability, sexual orientation, indigeneity and geographic location - interact with gender to shape how different people engage with conflict and peacebuilding' (ibid.: 4).

Close et al. (2020: 5) also set out how to integrate gender into a 'systems approach', with systems analysis 'increasingly used by peacebuilding practitioners to identify patterns of behaviour, decisions, and interaction in complex conflict scenarios in order to transform violence'. They note:

'This is a way of seeing the interconnectedness of structures, behaviours and relationships in conflicts to help identify the causes and impacts of the conflict, uncover opportunities for peace, and understand how the people involved in sustaining conflict or working for peace interact and influence each other' (ibid.).

\section{Humanitarian vulnerability, resilience and needs assessments}

There is guidance for gender and intersectional analysis at times of humanitarian emergencies. The United Nations Office for the Coordination of Humanitarian Affairs (OCHA) provides various tools and guidance for joint needs assessments and analysis. For example, the Inter-Agency Standing Committee (IASC) multi-sector initial rapid assessment (MIRA) guidance 'explains how to jointly design and execute a joint, multi-sectoral needs assessment in the initial weeks of an emergency' as 'a precursor to subsequent cluster/sectoral needs assessments'. ${ }^{13}$ The MIRA applies a geographical and vulnerability lens to identify immediate needs in a rapid-onset emergency such as a disaster (IASC, 2015).

There has been a focus on gender analysis within humanitarian needs assessments and situational analyses (IASC, 2018: 31). The CARE rapid gender analysis tool ${ }^{14}$ is used to conduct gender analysis quickly during an emergency response... throughout the HPC [humanitarian

\footnotetext{
${ }^{12}$ https://www.c-r.org/learning-hub/gender-sensitive-conflict-analysis-facilitators-guide (See Section 5 for a summary) This draws on Conciliation Resources (Tielemans 2015) and Saferworld and Uganda Land Alliance (Wright et al., 2017) toolkits applying an intersectional approach to analysing gender, conflict and peace dynamics.

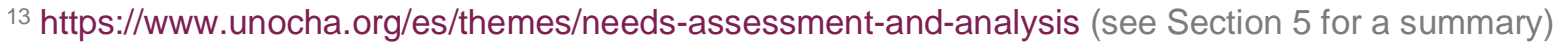

${ }^{14}$ http://gender.careinternationalwikis.org/_media/gie_guidance_note_rapid_gender_analysis.pdf (see Section 5 for a summary)
} 
programme cycle] and adapted for different sectors using the relevant guidance on needs analysis' (ibid.: 32). It can 'be done progressively with understanding deepening as more information becomes available' (ibid.). There are many examples of rapid gender analyses: one example is the analysis undertaken for the Middle East and North Africa region by Phelps (2020) as a secondary data review from 31 March to 5 April 2020. That review summarised information about the various needs, capacities and coping strategies of women, men, girls and boys in the region during the COVID-19 pandemic. The first recommendation of the review was to 'consistently collect and analyze sex, age, and disability disaggregated (SADD) data in all preparedness and response interventions' (Phelps, 2020: 2).

A recent OCHA initiative seeks to apply an intersectional lens to consider 'Key vulnerability characteristics (including based on age, gender and disability and other contextually relevant characteristics)' in a framework for assessing intersectoral needs of populations in crises (OCHA, 2021: 14). This initiative - the Joint Intersectoral Analysis Framework (JIAF) ${ }^{15}$ - is being developed and rolled out.

Analytical frameworks to guide protection ${ }^{16}$ analysis in crisis settings also consider intersectional vulnerabilities. In a Framework for Protection Risk Analysis, ${ }^{17}$ InterAction (2020) notes that: 'vulnerability may be a function of location; time; gender; age; disability; occupation; social, religious, economic or political group; ethnicity, culture or tradition; etc.' This InterAction framework and the Global Protection Cluster (2021: 3) Protection Analytical Framework ${ }^{18}$ set out the process and questions to analyse existing information on threats (violence, coercion and deliberate deprivation), vulnerabilities, risk and capacity to inform 'strategies that reduce and prevent protection risks that may violate international human rights and refugee and humanitarian laws'.

\section{Lessons learned}

\section{Embedding analysis in strategy and programme decision-making}

Published guidance stresses the importance of 'embedding' GESI analyses in an organisations' strategy and programme cycle. This requires a move away from 'one-off' products by external 'experts' to 'an operational tool that allows programme staff to undertake on-going analysis, learn from changes on the ground and continually adapt strategies and approaches in response to changing contexts and pushbacks from powerholders' (Christian Aid and Social Development Direct, 2021a: 20). This will enable the analysis to become 'an integrated element of [programme teams' and partners'] day-to-day work and the programme's strategic direction' (ibid.). Lessons

\footnotetext{
${ }^{15} \mathrm{https}: / / w w w . j i a f . i n f o /$ and https://kmp.hpc.tools/km/2022-jiaf-guidance (See Section 5 for a summary)

${ }^{16}$ The IASC definition of protection is: 'all activities aimed at obtaining full respect for the rights of the individual in accordance with the letter and the spirit of the relevant bodies of law, including International Human Rights Law (IHRL), International Humanitarian Law and International Refugee Law (IRL)'. (Global Protection Cluster, 2021: 5).

17 https://protection.interaction.org/interactions-framework-for-protection-risk-analysis/ (see summary in Section 5)

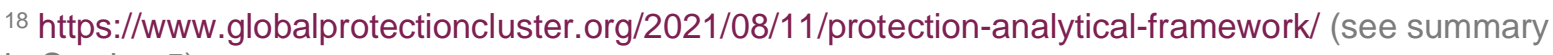
in Section 5)
} 
can be drawn from other toolkits (such as CARE's Rapid Gender Analysis toolkit), ${ }^{19}$ which support rolling (not one-off) analysis.

The analysis needs to be started early enough in the process to inform strategic priorities and key design decisions. Learning from a GESI approach to accountability work in Somalia cautions that 'it is extremely difficult to retro-fit meaningful engagement on GESI issues into established projects' (Haegeman and Grant, 2017: 10).

Recommendations for supporting internal organisational engagement with, and uptake of the findings of, intersectional analysis include:

- investing in supportive policy, strategy and programme initiatives. Munro (2016: 6), looking at the development community progress on the pledge to Leave No One Behind (LNOB), recommended donors "build inclusive programming criteria and "leave no one behind" markers into all business cases across all sectors and include "leave no one behind" criteria in their structural support to governments'. The UN set out their intention for a 5step operational 'minimum standards' on adopting a LNOB approach, in line with commitment of the UN Chief Executive Board (UNSDG, 2019: 6), while all UK FCDO programmes and policies 'must consider and provide evidence, wherever relevant, on how their interventions will impact on gender equality, disability inclusion and those with protected characteristics'20 (FCDO, 2021: 30). Donors are also investing in GESI strategies, at the country, sector and programme level. ${ }^{21}$

- involving staff across operational processes and hierarchy, including head of office, crossdisciplinary staff and in-country staff (DFID, 2009b: 21).

- investing in a 'more participatory approach, where programme staff build on their own political and social intelligence to produce an analysis that they know, understand, and are able to update regularly' noting that this 'is much more likely to be used in day-to-day work and lead to better programming' (Haines and O'Neil, 2018: 9).

- planning from the start 'for follow-up activities (e.g. action-oriented workshops) to ensure that the analysis feeds directly into strategies and programmes' and developing 'appropriate process and outcome indicators to monitor progress and impact over time' (DFID, 2009b: 23).

\footnotetext{
${ }^{19}$ https://insights.careinternational.org.uk/in-practice/rapid-gender-analysis

20 The protected characteristics are specified in the Equality Act (2010) Public Sector Equality Duty (2010), which requires: 'evidence of due regard for tackling discrimination, advancing equality of opportunity and fostering good relations between those who share any of nine protected characteristics (sex, age, disability status, sexual orientation, race, religion or belief, pregnancy/maternity, marriage or civil partnership, and gender reassignment) and those who do not' (FCDO, 2021: 30).

${ }^{21}$ Examples include the GESI strategy for local health system sustainability produced for USAID (Local Health System Sustainability Project (LHSS) under the USAID Integrated Health Systems IDIQ., 2019); and the GESI Strategy 2018-2022 for the Australian funded governance programme KOMPAK in Indonesia (KOMPAK, 2018). This rapid review did not find published GESI strategies for individual crisis contexts.
} 


\section{Planning the analytical process: ethics, inclusive engagement and safeguarding}

Guidance for conducting analysis in crisis settings highlight the importance of taking a conflictsensitive approach that seeks to ensure that the process and outcomes do not cause harm (e.g. 'through raising expectations, placing key informants at risk') (Stabilisation Unit, 2017: 1; Close et al., 2020: 73; Christian Aid and Social Development Direct, 2021b: 64). This involves planning for potential ethical dilemmas and risks that might arise during and because of a GESI analysis; and responses to these. Previous DFID ethical guidance for research, evaluation and monitoring sets out key ethics standards and dilemmas across the research cycle (Thorley and Henrion, 2019). The key standards for ethical conduct of research, monitoring and evaluation activities include ensuring: (Thorley and Henrion, 2019: 4)

- 'Design and conduct of research, evaluation and monitoring work is sensitive to cultural, socioeconomic, environmental and political context.

- Harms to individuals and communities are minimised and benefits maximised, risks are identified, and mitigating actions are taken.

- Identity and confidentiality is protected and data are secure.

- Participation is based on informed consent.

- People's rights and dignity are respected and there is equitable participation.

- Findings are disseminated to intended beneficiaries and used appropriately.'

Conscious and unconscious bias can affect the analytical process (and findings). ${ }^{22}$ Useful issues to think through at the start of the process are team composition (with gender and age balance as a minimum); who is choosing what is included and what is left out of the analysis, and what type of evidence and sources are prioritised and why. ${ }^{23}$ These are important considerations key to avoid reinforcing existing power structures and exclusion (Thorley and Henrion, 2019: 15).

Guidance on GESI analysis recommends engagement with stakeholders throughout the research process, including government, civil society and beneficiaries. This engagement may take various forms including: 1) establishing multi-stakeholder reference groups; 2) participatory research methodologies; and 3) dissemination meetings (WHO, 2020: 19-20).

There are published approaches and toolkits setting out methodologies and providing practical tools for conducting participatory and inclusive research, some specifically for GESI analysis and others for crisis settings. For example, IASC (2018: 37) sets out guidelines for conducting rapid gender analysis in emergencies and provides simple solutions to common problems that can arise. Other resources include:

\footnotetext{
22 ACAPS (2016) provides an analysis of the common cognitive (selection, social and process) biases in humanitarian analyses and mitigation strategies.

${ }^{23}$ In its guide for CSOs, CIVICUS (2020) sets out guidelines for reviewing available data sources when undertaking a rapid situational analysis. They include, as well as government, international organisation and academic data, also citizen-generated data, such as 'websites that empower communities to map incidences of crime and thus increase their security' (CIVICUS, 2020: 43). One example is the I Paid A Bribe website in India; another is HarrassMap in Egypt, which maps incidents of sexual harassment in public places.
} 
- GIPP: Gender Inclusion, Power \& Politics Analysis Toolkit (Christian Aid and Social Development Direct, 2021a, b) - a complete toolkit with participatory approaches and tools for undertaking GESI analysis. This guidance specifies that Gender, Inclusion, Power and Politics analysis 'should not be a centralised top-down process as is often the practice of governments, donors or other international agencies. Analysis should be bottom-up, led by communities, individuals and groups who are marginalised, programme implementers and partners to ensure that they drive and fully own the analysis process' (Christian Aid and Social Development Direct, 2021a: 9).

- Facilitation Guide. Gender-sensitive Conflict Analysis. Conciliation Resources and Saferworld (Close et al., 2020) - a facilitation guide to undertaking gender-sensitive conflict analysis, including detailed step-by-step guidance and handouts for a flexible and participatory three-day workshop.

- Human-centred Design in Humanitarian Settings: Methodologies for Inclusivity (Hamilton et al., 2020) - methodologies for inclusivity in human-centred design in humanitarian settings.

- Research for All: Making Development Research Inclusive of People with Disabilities (Research for Development Impact (RDI) Network, 2020) - a guide to making development research inclusive of people with disabilities.

- SAGE Handbook of Participatory Research and Inquiry (Burns et al., 2021) - setting out how to design effective participatory research processes; and providing detailed accounts of how to use a wide range of participatory research methods, including approaches to engaging the poorest and most marginalised people. ${ }^{24}$ There is also a chapter on using participatory action research in conflict settings.

Consultations with stakeholders, beneficiaries and civil society for analysis in crisis settings will have context-specific sensitivities and potential risks (as well as benefits), and require careful safeguarding. These include protection-centred processes to ensure confidentiality, sensitivity, integrity, informed consent, safeguarding of recorded information, and diverse participation and inclusion (UNHCR, 2017: 33-34). It is important to set out the referral process for safeguarding issues that may come up, either from the analytical process or its findings (key safeguarding questions to consider are set out by Thorley and Henrion, 2019: 10-11).

Collaboration with local experts and organisations can be a key strategy for ensuing locally grounded analysis (DFID, 2009b: 21). OCHA (2021: 10-11) provides practical recommendations for ensuring the inclusion and active participation of local actors in a joint intersectoral analysis process. These include inviting local actors to be part of the analysis teams 'either as local data scientists/analysts and/or persons with "contextual and cultural expertise"' and empowering them to be active participants in meetings and discussions, ensuring language is not a barrier, and subsidising or fully reimbursing participation costs (ibid.). Local organisations - including women's rights organisations, women-led organisations, organisations of people with disabilities, older people's organisations and faith-based organisations, among others - are important sources of information and key stakeholders to engage with. However, it is important to consider who is being represented within these organisations, who are the gatekeepers and what the local power dynamics are (e.g. might the participation of faith-based organisations lead to the exclusion of LGBTQ+ activists) (expert comment). Published guidance highlights the importance of, as a first

24 https://www.ids.ac.uk/publications/the-sage-handbook-of-participatory-research-and-inquiry/ 
step, mapping 'key people who should be involved throughout your research cycle from inception to dissemination' (WHO, 2020: 19). Key considerations include whose voices are being heard and whose are not, bearing in mind those affected most by social inequalities and discrimination are at most risk of being marginalised within the research process.

GESI analysis in crisis settings can be politically sensitive. In crisis settings, for example, exploring the issue of exclusion based on religious and/or ethnic identity is often highly sensitive and difficult to do. In some contexts, human rights defenders and activists working on gender equality and/or the rights of people with diverse sexual orientation, gender identity and/or expression, and sex characteristics face persecution from authorities. Das (2016: 20) notes that:

'Some group-based identities may be politically sensitive in certain countries. These include inter alia, migrant status, religion, sexual orientation, and even ethnicity. In some countries, analysis that highlights disparities across ethnicity or religion [can] be perceived by the state as provoking inter-group tensions or as undermining the development of a common national identity. Still other countries may have explicit policies that ban references to ethnicity in public speeches or official documents, and may prevent the collection or public use of data on ethnic identity.'

In terms of engaging with governments and national partners, DFID political economy analysis guidance recommended judging the scope for this 'on a case-by-case basis', noting that where full disclosure of findings proved difficult, disseminating key findings or summaries 'has often laid the basis for a more productive policy dialogue going forwards' (DFID, 2009b: 22).

From their experience supporting a GESI approach to accountability work in Somalia, Haegeman and Grant (2017) set out some useful learning on how to support inclusive engagement with marginalised groups in this fragile and insecure context. With excluded groups needing extra support to overcome barriers, while needing to meet resistance that may arise, effective inclusion strategies include: (ibid.: 9-12)

- 'Pre-training and preparation of women and other vulnerable and marginalised groups, prior to engagement with others in broader community platforms or spaces'.

- 'Careful (and neutral) mediation in safe spaces can help convince excluded groups that participation is meaningful'.

- Identifying and engaging with groups that act as 'key platforms to mobilise, galvanise and give voice to marginalised groups', for example, 'women's associations, including business associations and credit / self-help groups) and youth groups'.

- Considering diverse and tailored communication, responding to low levels of literacy and showcasing positive examples of engagement by marginalised groups.

- 'Finding ways to convince those in power of the value of inclusivity': resistance from local authorities on consultation with women and other excluded groups was turned around by taking the time to explain the need for more inclusive engagement.

\section{Applying an 'intersectional' analytical lens}

The literature provides various insights on how to start and shape intersectional analysis, most of these findings are relevant to all settings; some are particularly pertinent for crisis settings.

Applying an 'intersectional' analytical lens has methodological challenges. There is the risk of intersectional analysis being interpreted as requiring a 'listing out' of every possible category of 
vulnerability and intersections between marginalisations that is 'exhaustive' (George et al., 2021: 3). Potential issues include focusing on individual identities 'delinked from systemic power hierarchies' (Michelis, 2020: 6); or to put it another way, ending up with a depoliticised approach that identifies difference but does not explore causal power and oppression dynamics, or identify opportunities to address these (Homan et al., 2018: 505).

To address these risks, the literature highlights the importance of ensuring the analysis is contextualised. In other words that it investigates what is happening locally rather than relying on assumptions, given that realities differ depending on context (Wright et al., 2017: 5 of section 1). There are risks in using a generic checklist of social identifiers that is not context specific. Brigden and Ahluwalia (2020: 10) relate how in Iraq, 'a consortium delivering an Australian government funded project, Building Peaceful Futures, aimed at supporting the return and reintegration of returnees, strengthening community resilience and social cohesion through inclusive services'. The project started by analysing how in the two locations disability, gender, age and diversity were impacting on access to services, decision-making structures and human rights. 'However, the adapted tool was context-blind, including to conflict sensitivity', and risked overlooking the role of faith, ethnic and tribal identity 'which intersect with gender, disability and age to create barriers to services, drive exclusion and discrimination' (ibid.). When contextual factors are not taken into account, this could reinforce discrimination and deepen societal differences and tensions (Brigden and Ahluwalia, 2020: 11).

The analytical frameworks emphasise the importance of reviewing existing evidence and analysis, to avoid duplication of effort and help identify appropriate analytical entry points. For example, an initial rapid desk-based problem analysis could look to identify 'systemic issues, blockages and entry points, structural divides and inequalities, influential social norms and behaviours, etc.' (Christian Aid and Social Development Direct, 2021a: 26). Key issues could include 'systemic exclusion of voice and influence in service delivery for marginalised groups, discrimination, divided or co-opted civil society, failures of accountability, etc.' (ibid.).

The literature recommends going beyond a single 'vulnerable group' perspective, and understand how underlying power dynamics shape people's life experiences. On the one hand, 'an intersectional understanding of gender relations' is advanced in the analytical guidance reviewed, and in academic studies (Cochrane and Rao, 2019: 61). However, in practice 'gender analysis' has sometimes been reduced to a limiting focus on 'women and girls' alone as an innately vulnerable category and achieving sex disaggregation of data, while failing to grasp the intersections between different power hierarchies and forms of oppressions as a way of understanding differences in lived experiences' (Lokot and Avakyn, 2020: 42; Cochrane and Rao, 2019). In their article on the value of an intersectional lens for understanding barriers to accessing sexual and reproductive health in humanitarian settings, Lokot and Avakyn (2020: 42) suggest 'asking the question of "which women and girls?" to understand how gender inequality overlaps with other forms of systemic discrimination, such as racism, ableism and homophobia'.

Another recommendation in the guidance reviewed is that using a systems approach and mapping in the analysis to illuminate the links between different drivers and dimensions of exclusion, can make it easier to capture the links between different elements and identify 'the strongest opportunities to influence the system' (Close et al., 2020: 6).

The literature also highlights the importance of taking into account commonly neglected issues: resilience and areas of agency and empowerment; men and boys; and masculinities. On resilience, George et al. (2021: 3) caution that: 
'as the focus on intersectionality is often primarily on experiences of inequality and exclusion, approaches to intersectionality can risk focusing too heavily on "victimhood" and "vulnerability" of people, failing to focus sufficiently on their agency and areas of empowerment in relation to diverse identities.'

One attempt to address this gap is the collective capabilities conceptual framework of the Gender and Adolescence: Global Evidence (GAGE) longitudinal research on adolescent lives in six lowand middle-income countries from 2015 to 2024 (Baird et al., 2021). It engages with how adolescents' capabilities - and disadvantages of particular groups - are shaped by the broader sociocultural, economic and political contexts in which they grow up. It focuses on 'collective capabilities', as a deliberate attempt to recognise 'the power of groups working together towards shared goals of empowerment and capability expansion' (Baird et al., 2021: 1149). In addition, development research has focused on women and girls, but it is just as important to understand 'how gender affects men, boys and people with non-binary identities' (WHO, 2020: 18). In fragile and conflict-affected situations, societal expectations of male behaviour can play an important role 'in advancing or constraining peace, recovery and gender equality' (OECD, 2021: 8). For example, a report analysing social norms at the household and community levels in two research locations in Myanmar finds that 'expectations of masculinity can drive behaviour that exacerbates or leads to an increase in violent conflict, and pose different types of vulnerabilities for men living in these conflict contexts' (Naujoks and Ko, 2018: 5).

Lastly, there is thematic guidance on the key issues (and evidence) pertinent to intersecting social inequalities, including for areas that traditionally may not have taken these into account. For example:

- The Guidance Note for Implementing Strategic Outcome 6: Preventing and Countering Violent Extremism for the UK National Action Plan on Women, Peace and Security 20182022 sets out the key issues involved in, and how to undertake, gender-sensitive conflict analysis of the violent extremist context (Lockett et al., 2019).

- The Disability Inclusion Helpdesk has produced a series of inclusion profile factsheets 'to enhance knowledge and understanding of how different identities are impacted by poverty', including for people with disabilities, people with mental health conditions, young people, older people, LGBT people, women and girls, and indigenous peoples and people from minority ethnic groups. ${ }^{25}$

\footnotetext{
${ }^{25}$ https://www.sddirect.org.uk/our-work/disability-inclusion-helpdesk/
} 


\section{Appendix: Overview of analytical frameworks}

\begin{tabular}{|c|c|c|c|c|c|}
\hline $\begin{array}{l}\text { Title and link to } \\
\text { report }\end{array}$ & Author & Analytical focus & Key research questions & $\begin{array}{l}\text { Analytical process and } \\
\text { research methods }\end{array}$ & Other \\
\hline \multicolumn{6}{|c|}{ A. Gender equality and social inclusion analytical frameworks } \\
\hline $\begin{array}{l}\text { How to Note: } \\
\text { Gender and Social } \\
\text { Exclusion Analysis } \\
\text { (2009) }\end{array}$ & DFID & $\begin{array}{l}\text { Focus on formal and } \\
\text { informal processes in the } \\
\text { three main spheres of } \\
\text { people's lives - society, the } \\
\text { state and the market - in } \\
\text { which political, economic, } \\
\text { social and institutional } \\
\text { factors interact in } \\
\text { discriminatory - or non- } \\
\text { discriminatory - ways. }\end{array}$ & $\begin{array}{l}\text { Questions on: } \\
\text { - Society - vulnerability; intra- } \\
\text { household relations; social and cultural } \\
\text { practices; traditional local, religious, } \\
\text { and community governance; civil } \\
\text { society and media; social cohesion, } \\
\text { violence and conflict. } \\
\text { - Market - income and employment; } \\
\text { assets; overall economic growth. } \\
\text { - State - citizenship; voice and } \\
\text { accountability; formal political } \\
\text { systems; policy; public services; legal } \\
\text { framework; politics. }\end{array}$ & $\begin{array}{l}\text { - Analysis scope depends on } \\
\text { country context, available data, } \\
\text { resources and time-frame. May } \\
\text { be completed relatively quickly } \\
\text { using existing secondary } \\
\text { sources. } \\
\text { - Consultation with local } \\
\text { stakeholders important for } \\
\text { reality check, building } \\
\text { relationships and consensus. } \\
\text { - Highlights need to consider } \\
\text { time, resources, skills for } \\
\text { engaging with marginalised } \\
\text { groups. }\end{array}$ & $\begin{array}{l}\text { - Provides a suggested } \\
\text { structure for final report. } \\
\text { - Highlights need for forward- } \\
\text { looking risk scenarios posed } \\
\text { by gender inequality and } \\
\text { social exclusion. } \\
\text { - Considers wider policy } \\
\text { environment (government, } \\
\text { civil society, international } \\
\text { community and private sector } \\
\text { response). } \\
\text { - Detailed guidance on data. }\end{array}$ \\
\hline $\begin{array}{l}\text { GIPP: Gender, } \\
\text { Inclusion, Power } \\
\text { and Politics } \\
\text { Analysis Toolkit } \\
\text { (2021a, b) } \\
\text { Part 1 and Part } 2\end{array}$ & $\begin{array}{l}\text { Christian Aid and } \\
\text { Social } \\
\text { Development } \\
\text { Direct (CA and } \\
\text { SDD) }\end{array}$ & $\begin{array}{l}\text { Integration of GESI, power, } \\
\text { and political economy } \\
\text { analysis. Focus on: } \\
\text { - 'Context, Actors and } \\
\text { Institutions' - who is } \\
\text { excluded, context } \\
\text { factors, formal and } \\
\text { informal institutions, } \\
\text { social and political } \\
\text { network mapping; and } \\
\text { - 'Power (Incentives and } \\
\text { Behaviours)'-looking at } \\
\text { 'What influences and } \\
\text { motivates actors to }\end{array}$ & $\begin{array}{l}\text { - 'Where power lies, who it lies with, } \\
\text { who is excluded and why? } \\
\text { - How is the lack of power itself a } \\
\text { form of poverty? } \\
\text { - What are the forms, types and } \\
\text { spaces of power? (personal, } \\
\text { collective, public/private domains } \\
\text { etc) } \\
\text { - How do power dynamics and } \\
\text { political institutions shape } \\
\text { decisions/resource } \\
\text { allocation/inequality? } \\
\text { - Who uses and benefits from these } \\
\text { arrangements? }\end{array}$ & $\begin{array}{l}\text { - Promotes bottom-up process, } \\
\text { led by communities, individuals } \\
\text { and groups who are } \\
\text { marginalised, programme } \\
\text { implementers and partners, } \\
\text { with in-country multi- } \\
\text { stakeholder taskforce. } \\
\text { - Provides ethical guidelines, } \\
\text { outline of process steps. } \\
\text { - Provides complete toolkit with } \\
\text { participatory approaches and } \\
\text { tools with: 1) practical guide to } \\
\text { workshops, evidence gathering } \\
\text { and writing up the gender, }\end{array}$ & $\begin{array}{l}\text { - Emphasises and sets out how } \\
\text { to achieve an embedded, } \\
\text { adaptive and flexible analysis } \\
\text { in the project cycle. (CA and } \\
\text { SDD, 2021a: 20-25) } \\
\text { - Emphasises identification of } \\
\text { pathways of change and use } \\
\text { of this analysis to identify } \\
\text { hidden entry points and } \\
\text { champions of change (CA and } \\
\text { SDD, 2021a: 26-27) (including } \\
\text { evidence-based advocacy and } \\
\text { policy engagement by } \\
\text { marginalised groups) and }\end{array}$ \\
\hline
\end{tabular}




\begin{tabular}{|c|c|c|c|c|c|}
\hline $\begin{array}{l}\text { Title and link to } \\
\text { report }\end{array}$ & Author & Analytical focus & Key research questions & $\begin{array}{l}\text { Analytical process and } \\
\text { research methods }\end{array}$ & Other \\
\hline & & $\begin{array}{l}\text { behave as they do in } \\
\text { relation to specific } \\
\text { identified problems' } \\
\text { including 'Types of } \\
\text { relationships and power } \\
\text { dynamics' and 'Spaces } \\
\text { and Places of power - } \\
\text { where and what to } \\
\text { influence' (CA and SDD, } \\
\text { 2021a: 11) }\end{array}$ & $\begin{array}{l}\text { - What are the incentives, barriers } \\
\text { and potential new pathways for } \\
\text { change? } \\
\text { - How to enhance the agency and } \\
\text { voice of people who are excluded?' } \\
\text { (CA and SDD, 2021a: 13) }\end{array}$ & $\begin{array}{l}\text { inclusion, power and politics } \\
\text { analysis; 2) tools for analysis: } \\
\text { key informant interview and } \\
\text { focus group discussion } \\
\text { questions, workshop and report } \\
\text { templates. (CA and SDD, 2021b) }\end{array}$ & $\begin{array}{l}\text { potential blockers and } \\
\text { strategies for mitigating risk } \\
\text { (CA and SDD, 2021a: 16). }\end{array}$ \\
\hline $\begin{array}{l}\text { Social Inclusion } \\
\text { Assessment Tool } \\
\text { (SiAT) (2018) }\end{array}$ & World Bank & $\begin{array}{l}\text { Based on World Bank } \\
\text { (2013) 'Inclusion Matters'. } \\
\text { Focus is on: } \\
\text { - Identifying excluded } \\
\text { groups. } \\
\text { - Analysing why they are } \\
\text { excluded. } \\
\text { - Identifying actions to } \\
\text { advance social inclusion. } \\
\text { - Monitoring social } \\
\text { inclusion and results. }\end{array}$ & $\begin{array}{l}\text { 'IDENTIFICATION } \\
\text { 1. Are excluded groups identified? } \\
\text { Who is excluded? Are some groups } \\
\text { less likely to benefit from a } \\
\text { project/program/policy because of } \\
\text { their identity? } \\
\text { ANALYSIS } \\
\text { 2. Is here ex ante analysis on social } \\
\text { inclusion? } \\
\text { How and why is the particular group } \\
\text { (or groups) excluded? What drives } \\
\text { the exclusion? } \\
\text { ACTIONS } \\
\text { 3. Are there actions intended to } \\
\text { advance social inclusion? } \\
\text { Social Inclusion is not always about } \\
\text { doing more: it is often about doing } \\
\text { things differently. What actions are } \\
\text { built into project, program or policy } \\
\text { design? } \\
\text { MONITORING } \\
\text { 4. Are there indicators to monitor } \\
\text { social inclusion? }\end{array}$ & $\begin{array}{l}\text { - This tool is a short four-question } \\
\text { methodology to enable asking } \\
\text { the right questions. } \\
\text { - Draws on World Bank } \\
\text { methodology for poverty and } \\
\text { social impact analysis and how } \\
\text { to assess the extent to which } \\
\text { gender gaps are closed in } \\
\text { projects. }\end{array}$ & \\
\hline
\end{tabular}




\begin{tabular}{|c|c|c|c|c|c|}
\hline $\begin{array}{l}\text { Title and link to } \\
\text { report }\end{array}$ & Author & Analytical focus & Key research questions & $\begin{array}{l}\text { Analytical process and } \\
\text { research methods }\end{array}$ & Other \\
\hline & & & $\begin{array}{l}\text { How would we know if we have } \\
\text { made progress? In projects, does the } \\
\text { results framework contain indicators } \\
\text { on inclusion?' (World Bank, 2018:1) }\end{array}$ & & \\
\hline $\begin{array}{l}\text { Social Inclusion } \\
\text { Toolkit (2020) }\end{array}$ & CIVICUS & $\begin{array}{l}\text { Gives civil society } \\
\text { organisations (CSOs) } \\
\text { guidance on: } \\
\text { '1. Undertaking a } \\
\text { situational analysis and } \\
\text { data review, including } \\
\text { mapping current } \\
\text { initiatives, in order to } \\
\text { prioritise key excluded } \\
\text { groups 2. Interrogating } \\
\text { dimensions of exclusion } \\
\text { by utilising an } \\
\text { intersectional analysis } \\
\text { tool 3. Beginning to } \\
\text { integrate findings into } \\
\text { the programmatic } \\
\text { cycle, including } \\
\text { monitoring and } \\
\text { evaluation for } \\
\text { inclusion.' (CIVICUS, } \\
\text { 2020: 32) }\end{array}$ & $\begin{array}{l}\text { Provides a questionnaire for } \\
\text { undertaking: } \\
\text { 'a situational analysis to identify } \\
\text { excluded groups involved in and } \\
\text { affected by your work. A situational } \\
\text { analysis will help you to establish a } \\
\text { baseline of qualitative and } \\
\text { quantitative data and build an } \\
\text { overall picture of who is excluded, } \\
\text { the barriers they face and their } \\
\text { capacities for participation.' } \\
\text { (CIVICUS, 2020: 33) } \\
\text { Sets out domains of analysis (adapted } \\
\text { from United States Agency for } \\
\text { International Development (USAID) 2017 } \\
\text { 'Integrating Gender Equality and Female } \\
\text { Empowerment in USAID's Program } \\
\text { Cycle'): cultural gender norms; } \\
\text { discriminatory law and policies; access to } \\
\text { financial assets; access to technology and } \\
\text { the digital divide; access to educational } \\
\text { opportunities; vulnerability to the } \\
\text { adverse impacts of climate change; } \\
\text { gendered expectations of roles and } \\
\text { responsibilities in public and private life; } \\
\text { rural-urban differences in access to } \\
\text { services, infrastructure and poverty; } \\
\text { capacity to decide, influence and exercise }\end{array}$ & $\begin{array}{l}\text { Guiding principles: } \\
\text { - 'The process should be } \\
\text { conducted in a highly } \\
\text { participatory manner. } \\
\text { Efforts should be made to } \\
\text { reach out to excluded } \\
\text { groups and to design } \\
\text { channels for them to feed } \\
\text { into the process } \\
\text { meaningfully. } \\
\text { - Both quantitative and } \\
\text { qualitative data should be } \\
\text { gathered through the } \\
\text { process as a means of } \\
\text { gaining a comprehensive } \\
\text { understanding of exclusion } \\
\text { within your organisation. } \\
\text { - Considering the diverse } \\
\text { contexts in which cSOs } \\
\text { operate, it may be } \\
\text { necessary to situate } \\
\text { activities and translate } \\
\text { materials into relevant } \\
\text { languages.' (CIVICUS, 2020: } \\
\text { 32) }\end{array}$ & $\begin{array}{l}\text { Provides an overview of: } \\
\text { 'key historically excluded } \\
\text { groups and analyses current } \\
\text { global trends surrounding } \\
\text { their exclusion. It then } \\
\text { outlines an exercise that } \\
\text { CSOs can undertake to } \\
\text { apply this analysis to their } \\
\text { own contexts, taking into } \\
\text { consideration the local } \\
\text { cultural, political, economic } \\
\text { and social trends that shape } \\
\text { their experiences.' (CIVICUS, } \\
\text { 2020: 15) } \\
\text { Provides guidance on } \\
\text { integration of social inclusion } \\
\text { considerations into programme } \\
\text { design and across each stage of } \\
\text { the programme cycle. (CIVICUS, } \\
\text { 2020: } 47-53 \text { ) }\end{array}$ \\
\hline
\end{tabular}




\begin{tabular}{|c|c|c|c|c|c|}
\hline $\begin{array}{l}\text { Title and link to } \\
\text { report }\end{array}$ & Author & Analytical focus & Key research questions & $\begin{array}{l}\text { Analytical process and } \\
\text { research methods }\end{array}$ & Other \\
\hline & & & $\begin{array}{l}\text { control, including in state, private sector } \\
\text { and CSO voice and decision-making. } \\
\text { (CIVICUS, 2020: 45-46) }\end{array}$ & & \\
\hline $\begin{array}{l}\text { Incorporating } \\
\text { intersectional } \\
\text { gender analysis } \\
\text { into research on } \\
\text { infectious } \\
\text { diseases of } \\
\text { poverty: a toolkit } \\
\text { for health } \\
\text { researchers } \\
(2020)\end{array}$ & $\begin{array}{l}\text { World Health } \\
\text { Organization } \\
\text { (WHO) }\end{array}$ & $\begin{array}{l}\text { An infectious diseases of } \\
\text { poverty intersectional } \\
\text { gender analysis. Considers: } \\
\text { - Access to resources. } \\
\text { - Division of labour, roles } \\
\text { and everyday practices. } \\
\text { - Social norms and values. } \\
\text { - Rules and decision- } \\
\text { making. } \\
\text { Maps to infectious disease } \\
\text { domains (vulnerability to } \\
\text { disease/illness; ability to } \\
\text { prevent exposure; response } \\
\text { to illness). (WHO, 2020: 47) }\end{array}$ & $\begin{array}{l}\text { Detailed questions for the four analytical } \\
\text { areas. One example: } \\
\text { 'To what extent do men, women and } \\
\text { people with non-binary identities have } \\
\text { access to financial resources to pay } \\
\text { health care access or supplies? How } \\
\text { does this differ between different } \\
\text { groups of men, women and people with } \\
\text { non-binary identities?' (WHO, 2020: } \\
\text { 47) }\end{array}$ & $\begin{array}{l}\text { - Sets out the importance of, and } \\
\text { steps to, engaging with } \\
\text { stakeholders (communities and } \\
\text { decision makers) throughout } \\
\text { the research process. } \\
\text { - Outlines participatory research } \\
\text { methods and data collection } \\
\text { process. } \\
\text { - Provides guidance on analysing } \\
\text { quantitative and qualitative } \\
\text { research data using an } \\
\text { intersectional data lens. } \\
\text { - Outlines incorporating a gender } \\
\text { intersectional lens in } \\
\text { implementation research. }\end{array}$ & $\begin{array}{l}\text { Looks at gender considerations } \\
\text { in dissemination and reporting } \\
\text { of infectious disease research. }\end{array}$ \\
\hline $\begin{array}{l}\text { Gendered } \\
\text { political economy } \\
\text { analysis (2018) }\end{array}$ & $\begin{array}{l}\text { Haines and O'Neil } \\
\text { (for the Gender } \\
\text { and } \\
\text { Development } \\
\text { Network) }\end{array}$ & $\begin{array}{l}\text { Gendered stakeholder } \\
\text { analysis followed by } \\
\text { thinking about the social, } \\
\text { political and economic } \\
\text { factors that shape } \\
\text { stakeholders' motivations } \\
\text { and behaviour, and how } \\
\text { these affect men and } \\
\text { women differently. }\end{array}$ & $\begin{array}{l}\text { Rather than detailed questions, lists the } \\
\text { (visible and less visible) factors that } \\
\text { influence people's choices and } \\
\text { behaviour: 1) 'Formal rules and rights'; 2) } \\
\text { 'Social, cultural and economic structures } \\
\text { and norms'; 3) 'Values and beliefs'; 4) } \\
\text { 'Drivers of social or political change'. } \\
\text { (Haines and O'Neil, 2018: 15) }\end{array}$ & $\begin{array}{l}\text { Recommends: } \\
\text { 'A more participatory } \\
\text { approach, where programme } \\
\text { staff build on their own } \\
\text { political and social } \\
\text { intelligence to produce an } \\
\text { analysis that they know, } \\
\text { understand, and are able to } \\
\text { update regularly ...' (Haines } \\
\text { and O'Neil, 2018: 9) } \\
\text { Essential that diverse voices } \\
\text { participate, and women produce } \\
\text { some of the analysis. (p.9) }\end{array}$ & $\begin{array}{l}\text { Explains how a gendered } \\
\text { political economy analysis can } \\
\text { support 'a holistic diagnosis of } \\
\text { poverty and inequality'; 'avoid } \\
\text { reinforcing existing or historical } \\
\text { power imbalances'; 'diversify } \\
\text { our view of change pathways } \\
\text { and change agents' (Haines and } \\
\text { O'Neil, 2018: 2). Provides a } \\
\text { working example, showing some } \\
\text { of the factors that influence the } \\
\text { motivations and behaviour of } \\
\text { actors with an interest in the } \\
\text { justice system in rural } \\
\text { Bangladesh. }\end{array}$ \\
\hline
\end{tabular}




\begin{tabular}{|c|c|c|c|c|c|}
\hline $\begin{array}{l}\text { Title and link to } \\
\text { report }\end{array}$ & Author & Analytical focus & Key research questions & $\begin{array}{l}\text { Analytical process and } \\
\text { research methods }\end{array}$ & Other \\
\hline \multicolumn{6}{|c|}{ B. Gender-sensitive conflict analysis framework } \\
\hline $\begin{array}{l}\text { Facilitation guide: } \\
\text { Gender-sensitive } \\
\text { conflict analysis } \\
\text { (2020) }\end{array}$ & $\begin{array}{l}\text { Conciliation } \\
\text { Resources and } \\
\text { Saferworld (Close } \\
\text { et al., 2020) }\end{array}$ & $\begin{array}{l}\text { Integrates gender into a } \\
\text { systems approach, which } \\
\text { means examining: } \\
\text {-'gender as a system of } \\
\text { power - how symbolic } \\
\text { meanings; identities, } \\
\text { roles and relations; and } \\
\text { structures and } \\
\text { institutions work } \\
\text { together to fuel gender } \\
\text { inequality and cause } \\
\text { gendered conflict and } \\
\text { violence ..., } \\
\text { - how gender norms can } \\
\text { influence people's } \\
\text { behaviour towards } \\
\text { conflict or peace, } \\
\text { - the different impacts of } \\
\text { violence on women, girls, } \\
\text { men, boys, and sexual } \\
\text { and gender minorities } \\
\text { (SGMs), and } \\
\text { - the excluded actors in } \\
\text { the context due to these } \\
\text { (gendered) systems of } \\
\text { power.' (Close et al., } \\
\text { 2020:6) } 6 \text { ) }\end{array}$ & $\begin{array}{l}\text { Provides guidance for how to design } \\
\text { and facilitate a flexible and } \\
\text { participatory three-day gender- } \\
\text { sensitive conflict analysis (GSCA) } \\
\text { workshop. }\end{array}$ & $\begin{array}{l}\text { Meaningful participatory } \\
\text { approach. Aims to create space } \\
\text { to share the perspectives and } \\
\text { knowledge of people working } \\
\text { within communities and those } \\
\text { from marginalised groups. }\end{array}$ & $\begin{array}{lcc}\text { Recommends } & \text { taking } & \text { an } \\
\text { intersectional } & \text { approach } & \text { to } \\
\text { GSCA. } & & \end{array}$ \\
\hline
\end{tabular}




\begin{tabular}{|c|c|c|c|c|c|}
\hline $\begin{array}{l}\text { Title and link to } \\
\text { report }\end{array}$ & Author & Analytical focus & Key research questions & $\begin{array}{l}\text { Analytical process } \\
\text { and } \\
\text { methods }\end{array}$ & Other \\
\hline \multicolumn{6}{|c|}{ C. Humanitarian vulnerability, resilience and needs analysis } \\
\hline $\begin{array}{l}\text { Multi-Sector Initial } \\
\text { Rapid Assessment } \\
\text { Guidance - Revision } \\
\text { July } 2015 \text { (2015) }\end{array}$ & $\begin{array}{l}\text { Inter-Agency } \\
\text { Standing } \\
\text { Committee } \\
\text { (IASC) }\end{array}$ & 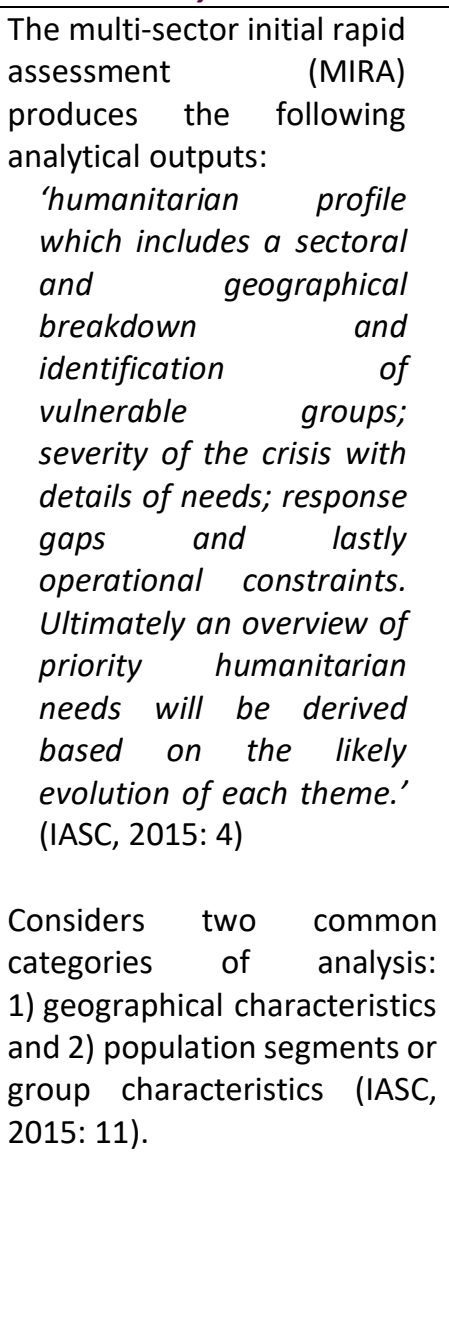 & 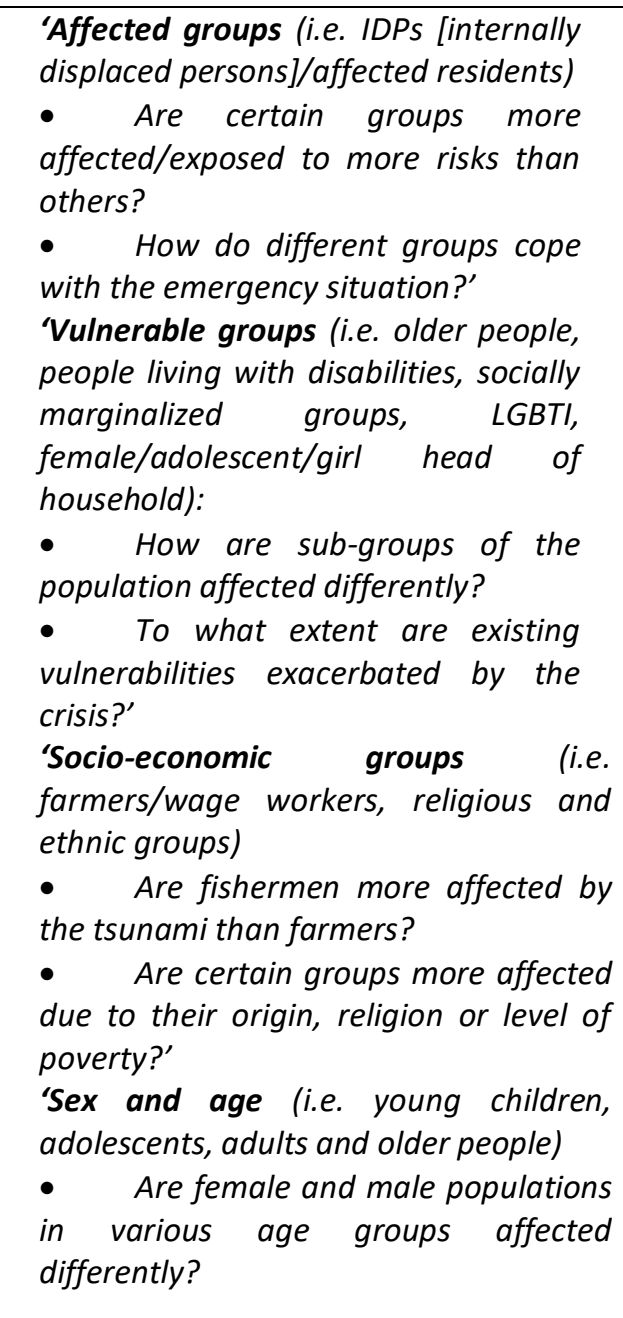 & 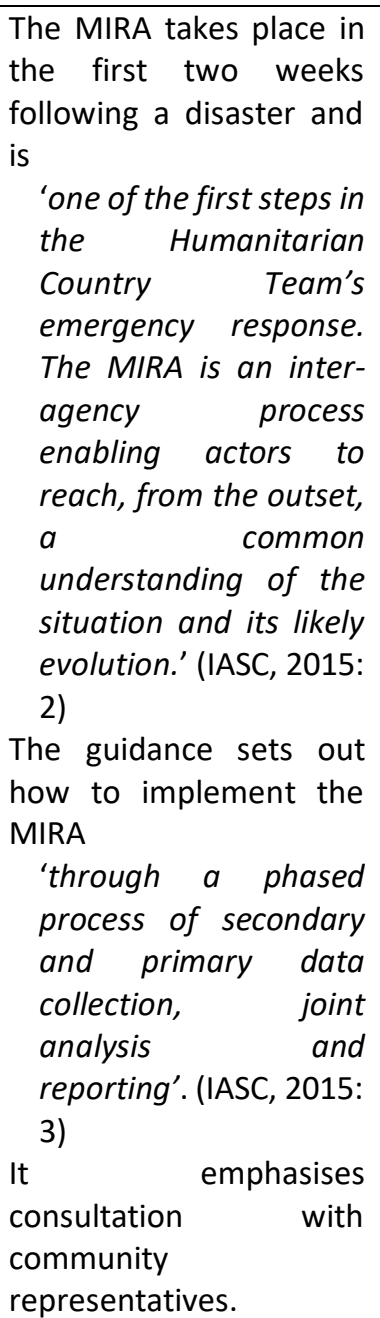 & $\begin{array}{l}\text { - Sets out in detail the phases, } \\
\text { with roles and } \\
\text { responsibilities for } \\
\text { coordination of a MIRA. }\end{array}$ \\
\hline
\end{tabular}




\begin{tabular}{|c|c|c|c|c|c|}
\hline $\begin{array}{l}\text { Title and link to } \\
\text { report }\end{array}$ & Author & Analytical focus & Key research questions & $\begin{array}{l}\text { Analytical process } \\
\text { and } \\
\text { methods }\end{array}$ & Other \\
\hline & & & $\begin{array}{l}\text { How do existing gender } \\
\text { inequalities contribute to the social and } \\
\text { economic vulnerabilities of the } \\
\text { population? } \\
\text { - Does the crisis exacerbate existing } \\
\text { gender-and age-based discrimination? } \\
\text { - Are different priority needs } \\
\text { expressed by the male and female } \\
\text { population?' (IASC, 2015: 11) }\end{array}$ & & \\
\hline $\begin{array}{l}\text { Gender in } \\
\text { Emergencies } \\
\text { Guidance Note: } \\
\text { Preparing a Rapid } \\
\text { Gender Analysis } \\
\text { (n.d.) (See here for } \\
\text { more on the CARE } \\
\text { rapid gender analysis } \\
\text { toolkit.) }\end{array}$ & CARE & $\begin{array}{l}\text { Overall, gender analysis in a } \\
\text { crisis tells us: } \\
\text { - Who is affected } \\
\text { (women, men, boys, girls, } \\
\text { elderly women, elderly } \\
\text { men)? } \\
\text { - Who needs protection } \\
\text { and how? } \\
\text { - Who has access to what } \\
\text { assets and services, and } \\
\text { what prevents others } \\
\text { from gaining access to } \\
\text { those services? } \\
\text { - What capacities of } \\
\text { women, men, boys and } \\
\text { girls to respond to the } \\
\text { crisis? } \\
\text { Whether women and men } \\
\text { participate equally in } \\
\text { decision-making? (p.1) }\end{array}$ & $\begin{array}{l}\text { - 'List the distinct capacities, needs } \\
\text { and preferences of women, men, girls } \\
\text { and boys. Are they the same since } \\
\text { before the crisis or have they changed? } \\
\text { - List the pertinent roles and } \\
\text { responsibilities for women, men, girls } \\
\text { and boys. Is there a fair workload } \\
\text { distribution? How does the distribution } \\
\text { affect their respective rights for } \\
\text { growth and opportunities? Who } \\
\text { makes decisions about the use of the } \\
\text { resources and are needs equitably } \\
\text { met? } \\
\text { - List the dynamics between women, } \\
\text { men, girls and boys. How do women } \\
\text { and men help or hinder each other to } \\
\text { meet their needs and rights? Who } \\
\text { perpetrates violence against whom? } \\
\text { What roles do the community and } \\
\text { institutions play in meeting needs and } \\
\text { rights, as well as addressing and } \\
\text { preventing violence?' (CARE, n.d.: 2-3) }\end{array}$ & $\begin{array}{l}\text { 'The Rapid Gender } \\
\text { Analysis is built up } \\
\text { progressively, using a } \\
\text { range of primary and } \\
\text { secondary information } \\
\text { to understand gender } \\
\text { roles and relations and } \\
\text { how these may change } \\
\text { during a crisis' (CARE, } \\
\text { n.d.: 1). } \\
\text { Includes rapid gender } \\
\text { analysis assessment tools } \\
\text { and guidance on } \\
\text { analysing pre- and post- } \\
\text { crisis data. }\end{array}$ & $\begin{array}{l}\text { Endorsed in the } 2018 \text { 'Gender } \\
\text { Handbook for Humanitarian } \\
\text { Action' (IASC, 2018). } \\
\text { Adapts gender analysis } \\
\text { approaches 'to the tight time- } \\
\text { frame, rapidly changing } \\
\text { contexts, and insecure } \\
\text { environments that often } \\
\text { characterise humanitarian } \\
\text { interventions'. (CARE, n.d.: 1) }\end{array}$ \\
\hline
\end{tabular}




\begin{tabular}{|c|c|c|c|c|c|}
\hline $\begin{array}{l}\text { Title and link to } \\
\text { report }\end{array}$ & Author & Analytical focus & Key research questions & \begin{tabular}{ll|}
$\begin{array}{l}\text { Analytical } \\
\text { and }\end{array}$ & process \\
methods &
\end{tabular} & Other \\
\hline $\begin{array}{l}\text { Joint Intersectoral } \\
\text { Analysis Framework } \\
\text { (JIAF) (2021) }\end{array}$ & $\begin{array}{l}\text { Office for the } \\
\text { Coordination of } \\
\text { Humanitarian } \\
\text { Affairs (OCHA) }\end{array}$ & $\begin{array}{l}\text { 'The JIAF provides } \\
\text { humanitarian actors with a } \\
\text { common analytical } \\
\text { framework and system to } \\
\text { gather, structure, and } \\
\text { synthesize information } \\
\text { regarding the intersectoral } \\
\text { needs of populations in } \\
\text { crisis.' (OCHA, 2021: 4) } \\
\text { Sets out in detail how to define } \\
\text { the scope of the JIAF analysis. } \\
\text { (OCHA, 2021: 12-13) }\end{array}$ & $\begin{array}{l}\text { No key research questions; instead, sets } \\
\text { out what the analysis aims to describe: } \\
\text { - 'The context or environment in which } \\
\text { humanitarian actors operate } \\
\text { (policies and legal framework, } \\
\text { security profile, socio-cultural and } \\
\text { demographics characteristics, } \\
\text { infrastructure, etc.). } \\
\text { - The exposure of the population to } \\
\text { different shocks and risks which } \\
\text { define the humanitarian crisis in the } \\
\text { given country (including } \\
\text { conflict/violence, human rights } \\
\text { violations, natural hazards, disease } \\
\text { outbreaks, etc.). } \\
\text { - Impact of the crisis on affected } \\
\text { population (including } \\
\text { displacement/mobility), systems and } \\
\text { services and humanitarian access. } \\
\text { - Key vulnerability characteristics } \\
\text { (including based on age, gender and } \\
\text { disability and other contextually } \\
\text { relevant characteristics). } \\
\text { - The linkages and causal factors } \\
\text { between all of above pillars.' (OCHA, } \\
\text { 2021: } 12,14 \text { ) }\end{array}$ & $\begin{array}{l}\text { It sets out that } \\
\text { 'The inclusion of local } \\
\text { and national actors is } \\
\text { necessary for } \\
\text { accountability and } \\
\text { fundamental to the } \\
\text { JIAF's ability to } \\
\text { accurately portray the } \\
\text { intersectoral needs of } \\
\text { the affected } \\
\text { population' provides } \\
\text { and on } \\
\text { recommendations on on an } \\
\text { how to achieve an } \\
\text { inclusive JIAF process. } \\
\text { (OCHA, 2021: 10) }\end{array}$ & $\begin{array}{l}\text { Has: 1) qualitative output } \\
\text { (narrative report); and } \\
\text { 2) quantitative output (the } \\
\text { severity of needs, determined } \\
\text { through a } 1-5 \text { severity scale; } \\
\text { and 3) the overall magnitude } \\
\text { of needs, represented by the } \\
\text { People in Need (PiN) figure. } \\
\text { (OCHA, 2021: 4) } \\
\text { This is an evolving approach } \\
\text { and development of the JIAF is } \\
\text { ongoing. }\end{array}$ \\
\hline $\begin{array}{l}\text { Protection Analytical } \\
\text { Framework (2021) }\end{array}$ & $\begin{array}{l}\text { Global } \\
\text { Protection } \\
\text { Cluster }\end{array}$ & $\begin{array}{l}\text { It considers context; current } \\
\text { threats to population; threats' } \\
\text { effects on population; existing }\end{array}$ & $\begin{array}{l}\text { No research questions but pillars and sub- } \\
\text { pillars are explained in more detail in the } \\
\text { protection analytical framework. } \\
\text { Considers: }\end{array}$ & $\begin{array}{l}\text { It applies the following } \\
\text { principles: people- } \\
\text { centred and inclusive; } \\
\text { continuous; competency } \\
\text { and capacity; use of } \\
\text { existing data and }\end{array}$ & Workflow guiding questions. \\
\hline
\end{tabular}




\begin{tabular}{|c|c|c|c|c|c|}
\hline $\begin{array}{l}\text { Title and link to } \\
\text { report }\end{array}$ & Author & Analytical focus & Key research questions & $\begin{array}{ll}\text { Analytical } & \text { process } \\
\text { and } & \text { research } \\
\text { methods } & \end{array}$ & Other \\
\hline & & $\begin{array}{l}\text { capacities to address } \\
\text { protection threats. } \\
\text { It is not a data collection tool; } \\
\text { it is used 'to organise data and } \\
\text { information from multiple } \\
\text { sources and existing } \\
\text { mechanisms'. (Global } \\
\text { Protection Cluster, 2021: 9) } \\
\text { It 'supports analysis at } \\
\text { different geographic levels, } \\
\text { including community, area, } \\
\text { country and cross-border'. } \\
\text { (ibid.) }\end{array}$ & $\begin{array}{l}\text { - 'Current factors that affect the } \\
\text { protection context, both positively and } \\
\text { negatively. } \\
\text { - Violations and abuse across } \\
\text { geographic locations and population } \\
\text { groups. } \\
\text { - The priority effects on the } \\
\text { population (affecting the dignity, } \\
\text { safety and well-being of the } \\
\text { population) arising from specific } \\
\text { violations and abuses for each } \\
\text { population group and geographic } \\
\text { location affected. } \\
\text { - Current combination of individual } \\
\text { capacity, local mechanisms, national } \\
\text { institutional capacity, and } \\
\text { humanitarian response capacity to } \\
\text { address violations and abuses.' (Global } \\
\text { Protection Cluster, 2021: 4) }\end{array}$ & $\begin{array}{l}\text { information; } \\
\text { coordination and } \\
\text { collaboration; action for } \\
\text { protection outcomes. } \\
\text { (Global Protection } \\
\text { Cluster, 2021: 6) }\end{array}$ & \\
\hline $\begin{array}{lr}\text { Framework } & \text { for } \\
\text { Protection } & \text { Risk } \\
\text { Analysis (2020) } & \end{array}$ & InterAction & $\begin{array}{l}\text { One-page framework on } \\
\text { threats (violence, coercion and } \\
\text { deliberate deprivation); } \\
\text { vulnerabilities; capacity; risks. }\end{array}$ & $\begin{array}{l}\text { It sets out questions to explore threats, } \\
\text { vulnerabilities, capacity and risk. For } \\
\text { example, on vulnerabilities: } \\
\text { 'Vulnerabilities } \\
\text { Who is vulnerable to this threat and } \\
\text { why? } \\
\text { Avoid generalizing who is vulnerable. } \\
\text { Being specific serves as the basis for } \\
\text { effective targeting of interventions to } \\
\text { reduce risk. } \\
\text { Vulnerability may be a function of } \\
\text { location; time; gender; age; disability; } \\
\text { occupation; social, religious, economic }\end{array}$ & $\begin{array}{l}\text { Gives examples and data } \\
\text { sources for continuous } \\
\text { analysis. }\end{array}$ & \\
\hline
\end{tabular}




\begin{tabular}{|l|l|l|l|l|}
\hline $\begin{array}{l}\text { Title and link to } \\
\text { report }\end{array}$ & Author & Key research questions & $\begin{array}{l}\text { Analytical process } \\
\text { and } \\
\text { methods }\end{array}$ \\
\hline research
\end{tabular}




\section{References}

ACAPS. (2016). Cognitive biases.

https://www.acaps.org/sites/acaps/files/resources/files/acaps_technical_brief_cognitive_bia ses_march_2016.pdf

Alder, C. (2021). Intersectional conflict analysis: Religion and gender (CSS analyses in security policy, no. 283). Center for Security Studies (CSS), ETH Zürich.

https://css.ethz.ch/content/dam/ethz/special-interest/gess/cis/center-for-securities-

studies/pdfs/CSSAnalyse283-EN.pdf

Baird, S., Camfield, L., Ghimire, A., Hamad, B.A., Jones, N., Pincock, K., and Woldehanna, T. (2021). Intersectionality as a framework for understanding adolescent vulnerabilities in low and middle income countries: Expanding our commitment to leave no one behind. Eur $J$ Dev Res 33, 1143-1162 (2021). https://doi.org/10.1057/s41287-021-00440-x

Barbelet, V. and Njeri, S. with Onubedo, G. (2021). Inclusion and exclusion in the north-east Nigeria crisis. HPG working paper. London: ODI. https://odi.org/en/publications/inclusionand-exclusion-in-the-north-east-nigeria-crisis/

Barbelet, V., and Wake, C. (2020). Inclusion and exclusion in humanitarian action. The state of play (Humanitarian Policy Group working paper). London: ODI.

https://cdn.odi.org/media/documents/Inclusion_and_exclusion_in_humanitarian_action_the _state_of_play.pdf

Birchall, J. (2021) Gender, intersectionality and Covid-19, Covid-19 Responses for Equity (CORE) blog, 15 July (accessed 23 September 2021)

Brigden, S., and Ahluwalia, K. (2020). Towards more inclusive practices: A disability, gender and age intersectional resource. Lyon/Paris: Humanity \& Inclusion/F3E. https://hi.org/sn_uploads/document/2020-

HI_DisabilityGenderAgelntersectionality_GN09.pdf

Burns, D., Howard, J., and Ospina, S. M. (Eds.). (2021). The SAGE handbook of participatory research and inquiry. SAGE. https://www.ids.ac.uk/publications/the-sage-handbook-ofparticipatory-research-and-inquiry/

CARE. (n.d.). Gender in emergencies guidance note: Preparing a rapid gender analysis.

http://gender.careinternationalwikis.org/_media/gie_guidance_note_rapid_gender_analysis .pdf

Carter, B. (2021). Impact of social inequalities and discrimination on vulnerability to crises. K4D Helpdesk Report 994. Brighton, UK: Institute of Development Studies. DOI:

10.19088/K4D.2021.049 https://opendocs.ids.ac.uk/opendocs/handle/20.500.12413/16541

Chaplin, D., Twigg, J., and Lovell, E. (2019). Intersectional approaches to vulnerability reduction and resilience-building. Resilience Intel, 12, 1-35. https://cdn.odi.org/media/documents/12651.pdf

Chataigner, P. (2017). A framework analysis of analytical frameworks. A review for the Joint inter-sectoral analysis group, August 2017.

https://assessments.hpc.tools/sites/default/files/km/170902\%20Analytical\%20Framework\% 20Review.pdf 
Christian Aid and Social Development Direct. (2021a). GIPP: Gender, inclusion, power \& politics analysis toolkit, Part 1- Guide. https://evidenceforinclusion.org/gipp-toolkit/

Christian Aid and Social Development Direct. (2021b). GIPP: Gender, inclusion, power \& politics analysis toolkit, Part 2 - Toolkit: Templates, tools and workshop plans.

https://evidenceforinclusion.org/gipp-toolkit/

CIVICUS. (2020). Social inclusion toolkit. http://civicus.org/documents/Social_Inclusion_Toolkit.pdf

Close, S., Groenewald, H., and Mora, D. T. (2020). Facilitation guide. Gender-sensitive conflict analysis. Conciliation Resources and Saferworld. London: Conciliation Resources. https://www.c-r.org/learning-hub/gender-sensitive-conflict-analysis-facilitators-guide

Cochrane, L., and Rao, N. (201). Is the push for gender sensitive research advancing the SDG agenda of leaving no one behind? Forum for Development Studies, Vol. 46(1), pp. 45-65). Routledge. https://doi.org/10.1080/08039410.2018.1427623

Crenshaw, K. (1989). Demarginalizing the intersection of race and sex: A black feminist critique of discrimination doctrine, feminist theory, and antiracist practice. University of Chicago Legal Forum, 89(1), Article 8, 139-67. https://chicagounbound.uchicago.edu/cgi/viewcontent.cgi?article=1052\&context=uclf

Das, M. B. (2016). Social inclusion in macro-level diagnostics: Reflecting on the World Bank group's early systematic country diagnostics (Policy research working paper, no. 7713). Washington D.C.: World Bank. https://openknowledge.worldbank.org/handle/10986/24630

DFID. (2009a). Gender and social exclusion analysis how to note (Practice paper, March 2009). Department for International Development (DFID). http://www.gsdrc.org/docs/open/se9. pdf

DFID. (2009b). Political economy analysis how to note (Practice paper, July 2009). Department for International Development (DFID).http://www.gsdrc.org/docs/open/po58.pdf

FCDO. (2021). FCDO programme operating framework (last updated - 20 May). https://assets.publishing.service.gov.uk/government/uploads/system/uploads/attachment_d ata/file/997874/Programme-Operating-Framework-June21.pdf

Foley, B. (2018). Intersectionality: A Marxist critique. Science \& Society, 82(2) (April 2018), 269275. https://doi.org/10.1521/siso.2018.82.2.269

Gaventa, J. (1982). Power and powerlessness: Quiescence and rebellion in an Appalachian valley. University of Illinois Press.

Global Protection Cluster. (2021). Protection analytical framework. An Introduction. https://www.globalprotectioncluster.org/2021/08/11/protection-analytical-framework/

Guglielmi, S., Jones, N., Nicolai, S., Pereznieto, P., Plank, G., Vu, N., Sanchez-Tapia, I., and Mackintosh, A. (2021). Reimagining girls' education: Solutions to keep girls learning in emergencies. UNICEF.

https://www.unicef.org/media/94201/file/Reimagining\%20Girls\%20Education\%20Solutions \%20to\%20Keep\%20Girls\%20Learning\%20in\%20Emergencies\%20.pdf

Haegeman, E., and Grant, E. (2017) Gender Equality and Social Inclusion Learning Brief. Implementation and Analysis in Action of Accountability Programme (IAAAP). Social Development Direct. https://www.sddirect.org.uk/media/1434/iaaap-kp5_gesi.pdf 
Haines, R., and O'Neil, T. (2018). Putting gender in political economy analysis: Why it matters and how to do it. Gender and Development Network. https://gadnetwork.org/gadnresources/2018/5/9/putting-gender-in-political-economy-analysis-why-it-matters-and-howto-do-it

Hamilton, Z., Casswell, J., and Alonso, A. (2020). Human-centred design in humanitarian settings: Methodologies for inclusivity (July 2020). London: GSMA. https://www.gsma.com/mobilefordevelopment/wpcontent/uploads/2020/09/Research_Methodologies_R1_Spreads-1.pdf

Homan, C., Chandran, D., and Lo, R. (2018). Young feminists working globally to end violence against women and girls: Key challenges and ways forward. Gender \& Development, 26(3), 495-513. https://doi.org/10.1080/13552074.2018.1525868

IASC. (2015). Multi-sector initial rapid assessment guidance - Revision July 2015. Inter-Agency Standing Committee (IASC). https://www.humanitarianresponse.info/en/programmecycle/space/document/multi-sector-initial-rapid-assessment-guidance-revision-july-2015

IASC. (2018). The gender handbook for humanitarian action, 2018. Inter-Agency Standing Committee (IASC). https://interagencystandingcommittee.org/iasc-reference-group-genderand-humanitarian-action/iasc-gender-handbook-humanitarian-action-2018

IASC. (2019). IASC guidelines, inclusion of persons with disabilities in humanitarian action, 2019. IASC Task Team on Inclusion of Persons with Disabilities in Humanitarian Action. InterAgency Standing Committee (IASC). https://interagencystandingcommittee.org/iasc-taskteam-inclusion-persons-disabilities-humanitarian-action/documents/iasc-guidelines

InterAction. (2020). Framework for protection risk analysis. Inter-Agency Standing Committee (IASC). https://protection.interaction.org/wp-content/uploads/2020/11/InterActionsFramework-for-Protection-Risk-Analysis.pdf

KOMPAK (2018). Gender equality and social inclusion strategy 2018-2022. August 2018. Jakarta: KOMPAK. https://www.dfat.gov.au/sites/default/files/indonesia-kompak-genderequality-and-social-inclusion-strategy.pdf

Local Health System Sustainability Project (LHSS) under the USAID Integrated Health Systems IDIQ. (2019). Local Health System Sustainability (LHSS) Gender Equality and Social Inclusion Strategy. Rockville, MD: Abt Associates. Prepared for the U.S. Agency for International Development. https://banyanglobal.com/wp-content/uploads/2020/05/LHSSGender-Equality-and-Social-Inclusion-Strategy.pdf

Lockett, K. with McGee, H., and Lindley-Jones, K. (2019). UK national action plan on women, peace and security 2018-2022: Guidance note - Implementing strategic outcome 6: preventing and countering violent extremism. https://assets.publishing.service.gov.uk/government/uploads/system/uploads/attachment_d ata/file/860174/UK_national_action_plan_women_peace_security_guidance_preventing_c ountering_violent_extremism_v2.pdf

Lokot, M., and Avakyan, Y. (2020) Intersectionality as a lens to the COVID-19 pandemic: implications for sexual and reproductive health in development and humanitarian contexts. Sexual and Reproductive Health Matters, 28:1, 1764748. https://doi.org/10.1080/26410397.2020.1764748

Lukes, S. (1974). Power: A radical view. London: Macmillan.

Maestripieri, L. (2021). The Covid-19 Pandemics: Why Intersectionality Matters. Frontiers in Sociology 6: 52. DOI: 10.3389/fsoc.2021.642662 
March, C., Smyth, I. A., and Mukhopadhyay, M. (1999). A guide to gender-analysis frameworks. Oxfam. https://policy-practice.oxfam.org/resources/a-guide-to-gender-analysisframeworks-115397/

Michelis, I. (2020). 'Picked up, misused, abused, changed': Intersectionality in the humanitarian discourse on gender-based violence (Research brief). https://cambridge.academia.edu/llariaMichelis

Munro, K. (2016). Leave no one behind: How the development community is realising the pledge. London: Bond. https://action4sd.org/wpcontent/uploads/2018/01/BOND.LeaveNoOneBehind.pdf

Naujoks, J., and Ko, M. T. (2018). Pulling the strings: Masculinities, gender and social conflict in Myanmar. International Alert, Phan Tee Eain (Creative Home), Thingaha Gender Organization. https://www.internationalalert.org/sites/default/files/Myanmar_MasculinitiesGenderSocialConflict_EN_2018_0.pdf

OCHA. (2021). 04 Joint intersectoral analysis framework 1.1: Humanitarian programme cycle 2022 (May 2021). https://www.jiaf.info/wp-content/uploads/2021/07/JIAF-1.1.pdf

OECD. (2021). Gender equality across the humanitarian-development-peace nexus. Paris: OECD Development Co-operation Directorate. https://www.oecd.org/dac/gender-equalityacross-the-hdp-nexus-july2021.pdf

Phelps, C. (2020). Rapid gender analysis: Middle East and North Africa region (Draft). CARE. http://www.careevaluations.org/wp-content/uploads/Regional-Rapid-Gender-

Analysis_MENA_10-April-2020_FINAL.pdf

RDI Network (2020). Research for all: Making development research inclusive of people with disabilities. CBM-Nossal Partnership for Disability-inclusive Development and Research for Development Impact (RDI) Network. https://rdinetwork.org.au/wpcontent/uploads/2020/06/RDI-Network-R4All-Accessible-PDF1.pdf?_cf_chl_jschl_tk_=pmd_F26ZRIRFeFqIXxMcDUL80EtgWQ91ttm1ljBr0TP7QqE1630930489-0-gqNtZ̄GzNAmWjcnBszQiR

Searle, L., Flint, J., Munyeki, M., and Watson, J. (2016). Inclusive humanitarian action: A study into humanitarian partnership agreement (HPA) agency practice in the Nepal Earthquake Response. Humanitarian Advisory Group. https://humanitarianadvisorygroup.org/insight/inclusive-humanitarian-action-a-study-intohumanitarian-partnership-agency-practice-in-the-nepal-earthquake-response/

Stabilisation Unit. (2017). Joint analysis of conflict and stability (JACS) guidance note. https://www.gov.uk/government/publications/joint-analysis-of-conflict-and-stability-jacsguidance-note

Thorley, L., and Henrion, E. (2019). DFID ethical guidance for research, evaluation and monitoring activities. Sheffield: IOD PARC.

https://assets.publishing.service.gov.uk/government/uploads/system/uploads/attachment_d ata/file/838106/DFID-Ethics-Guidance-Oct2019.pdf

Tielemans, S. (2015). Gender and conflict analysis toolkit for peacebuilders. Conciliation Resources. https://www.c-r.org/resource/gender-and-conflict-analysis-toolkit-peacebuilders

UNHCR. (2017). Needs assessment handbook. Geneva: UNHCR. https://im.unhcr.org/na/

UNSDG. (2019). Leaving No One Behind: A UNSDG Operational Guide for UN Country Teams. Interim Draft - 18 March 2019. UN Sustainable Development Group. 
https://unsdg.un.org/resources/leaving-no-one-behind-unsdg-operational-guide-un-countryteams

VeneKlasen, L. with Miller, V. (2002). A new weave of power, people \& politics: The action guide for advocacy and citizen participation. Oklahoma City, OK: World Neighbors.

https://www.participatorymethods.org/resource/new-weave-power-people-and-politicsaction-guide-advocacy-and-citizen-participation

WHO. (2020). Incorporating intersectional gender analysis into research on infectious diseases of poverty: a toolkit for health researchers. Geneva: World Health Organization (WHO). https://www.who.int/tdr/publications/year/2020/tdr-intersectional-gender-toolkit/en/

Wolfe, R., Molyneux, S., Morgan, R., and Gilson, L. (2017). Using Intersectionality to better understand health system resilience (Policy brief). RESYST.

https://resyst.Ishtm.ac.uk/sites/resyst/files/content/attachments/2018-08-

21/Resilience\%20and\%20intersectionality\%20brief.pdf

World Bank. (2013). Inclusion matters: The foundation for shared prosperity. New Frontiers of Social Policy. Washington, D.C.: World Bank.

https://openknowledge.worldbank.org/handle/10986/16195 License: CC BY 3.0 IGO.

World Bank. (2018). Social inclusion assessment tool (SiAT).

https://thedocs.worldbank.org/en/doc/478071540591164260-

0200022018/original/SiATSociallnclusionAssessmentTool.pdf

Wright, H., Watson, C., and Groenewald, H. (2017). Gender analysis of conflict toolkit. London: Saferworld and Uganda Land Alliance.

https://www.saferworld.org.uk/resources/publications/1076-gender-analysis-of-conflict

\section{Acknowledgements}

We thank the following experts who voluntarily provided suggestions for relevant literature or other advice to the author to support the preparation of this report. The content of the report does not necessarily reflect the opinions of any of the experts consulted.

- Oriana Castillo, CIVICUS

- Susan Erb, Anna Hanssen, Zarina Khan, Jessie Kirk, Tom Palmer, Morag Patrick, Toral Pattni, Lina Payne and Emmeline Skinner, FCDO

- Jo Howard and Philip Proudfoot, Institute of Development Studies

- Veronique Barbelet, Silvia Guglielmi, Nicola Jones and Kate Pincock, ODI

- Emma Haegeman, Social Development Direct

- Esther Waters-Crane, United Nations

- Maitreyi Bordia Das, World Bank

\section{Suggested citation}

Carter, B. (2022). Analysing intersecting social inequalities in crisis settings. K4D Helpdesk Report. Institute of Development Studies. DOI:10.19088/K4D.2022.003

\section{About this report}

This report is based on four days of desk-based research. The K4D research helpdesk provides rapid syntheses of a selection of recent relevant literature and international expert thinking in response to specific questions relating to international development. For any enquiries, contact helpdesk@k4d.info. 
K4D services are provided by a consortium of leading organisations working in international development, led by the Institute of Development Studies (IDS), with the Education Development Trust, Itad, University of Leeds Nuffield Centre for International Health and Development, Liverpool School of Tropical Medicine (LSTM), University of Birmingham International Development Department (IDD) and the University of Manchester Humanitarian and Conflict Response Institute (HCRI).

This report was prepared for the UK Government's Foreign, Commonwealth \& Development Office (FCDO) and its partners in support of pro-poor programmes. Except where otherwise stated, it is licensed for non-commercial purposes under the terms of the Open Government Licence v3.0. K4D cannot be held responsible for errors or any consequences arising from the use of information contained in this report. Any views and opinions expressed do not necessarily reflect those of FCDO, K4D or any other contributing organisation.

(c) Crown copyright 2022.

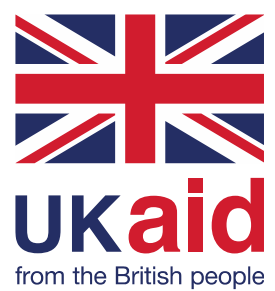

